\title{
変動軸力を考慮した杭基礎の地震応答に関する解析的検討 EARTHQUAKE RESPONSE OF PILE FOUNDATION CONSIDERING CONTRIBUTION OF AXIAL-FORCE FLUCTUATION IN PILES
}

\author{
酒 向 裕司*, 宮本 裕 司** \\ Yuji SAKO and Yuji MIYAMOTO
}

\begin{abstract}
Many pile foundations were severely damaged in the reclaimed land during the Hyogo-ken Nanbu Earthquake, January 17,1995 . The objective of this study is to investigate the contribution of axial-force fluctuation in piles to the responses of a pile foundation in the liquefied soil during earthquake. Earthquake response analyses of a structure on. a pile foundation. are conducted using the numerical model that takes into account the relationship between bending moment and curvature dependent. on axial force. These analytical results indicate that axial-force fluctuation in piles affects the elastic-plastic behavior of a pile foundation.
\end{abstract}

Keywords: pile non-linearity, earthquake response, interaction, axial-force fluctuation 杭体非線形, 地震応答, 相互作用, 軸力変動.

\section{1.はじめに}

1995 年 1 月 17 日に発生した兵庫県南部地震では、多くの杭基礎 に被害が発生した。杭被害の調查・分析結果から、主な被害原因と して、杭頭部では上部構造物からのせん断力: 転倒モーメントが、 地中部では地盤からの強制変形が杭体に過度の応力を生じさせたこ とが報告されている1，2)。筆者らも、ポートアイランド地点での 観測記録を入力動とした杭支持構造物の地震応答解析を行い、液状 化による地盤剛性の低下と地盤震動の増大が杭基礎の被害に大きく 影響を与えたことを指摘している ${ }^{3)}$.4)。このような被害を受け、 杭基礎の設計用地震荷重として従来の杭頭に作用させる上部構造物 からの慣性力に加えて、地盤震動による強制外力を考慮する設計法 の確立が緊急の課題となっている5 ${ }^{5) 。}$

一方、杭基礎の強度、変形性能は杭体に生じる軸力に依存するた め6)、杭基礎の被害メカニズムを解明するためには地震時に生じる 変動軸力の影響を検討する必要がある。変動軸力を考慮した検討と しては、茶谷らにより $\mathrm{RC}$ 杭の被害解析 ${ }^{j}$ が行われているが、軸力の 変化を取り入れながら建物の最大慣性力を静的に杭頭に作用させる 検討に止まっている。さらに、地盤震動による強制外力については 考虑されていない。また、現在実施に向けて検討がなされている性 能規定型設計では、地震荷重の大きさに応じた杭基礎の変形(被害) 状態を的確に把握することが必要となる。したがって、杭基礎の性 能評価においては、軸力に依存した杭体の強度・変形性能を考慮し て変形(被害)状態を評価することが重要となる。

このようなことから：本論文では杭体の復元力特性に軸力依存性
を取り入れた上部構造物一杭基礎一体とした地震応答解析法を示す。 応答解析では、兵庫県南部地震時のポートアイラシドでの観測記録 を入力動とした仮想の杭支持構造物の地震応答解析を実施し、変動 軸力による杭体の強度、変形性能の変化が杭基䃈の地震応答に及ほ す影響を明らかにする ${ }^{8)}$ 。また、上下動入力による構造物の上下応 答が杭体の軸力変動に及ぼす影響を把握するとともに、杭基礎の非 線形応答に与える影響についても検討する。

\section{2. 軸力依存を考慮した杭体の $M-\phi$ 関係}

\section{1 骨格曲線と履歴則}

軸力変動を考慮した杭体の曲げモーメントMー曲率 $\phi$ の復元力特 性は、次のように設定した。対象とする杭は、後の地震応答解析で 用いる場所打ちコンクリート杭とする。Table 1 に、杭断面の諸元を 示す。

場所打ちコンクリート杭の曲げモーメント $\dot{\mathrm{M}}$ 一曲率 $\phi$ の関係は 3 折れ線の骨格曲線とし、第 1 折れ点、第 2 折れ点、終局点は以下の ように設定する。

Table 1 Pile constants

\begin{tabular}{|c|c|c|}
\hline \multicolumn{2}{|c|}{ Diameter } & $1400 \mathrm{~mm}$ \\
\hline Concrete & $\begin{array}{c}\text { Compressive } \\
\text { Strength }\end{array}$ & $240 \mathrm{kgt} / \mathrm{cm}^{2}$ \\
\hline \multirow{2}{*}{ Steel Bar } & Yield Strength & $3500 \mathrm{kgt} / \mathrm{cm}^{2}(\mathrm{SD} 345)$ \\
\cline { 2 - 3 } & Steel Ratio & $1.2 \%(28-\mathrm{D} 29)$ \\
\hline
\end{tabular}

本論文の一部は，文献8)で既に発表している。

* 鹿島小堀研究室 主任研究員

** 鹿島小堀研究室 主管研究員 · 博士 (工学)
Senior Research Eng., Kobori Research Complex, Kajima Corp. Principal Research Eng., Kobori Research Complex, Kajima Corp., Dr. Eng. 
i ) 第 1 折九点 $\left(\phi_{\mathrm{c}}(\mathrm{N}) 、 M_{\mathrm{c}}(\mathrm{N})\right)$

縁部においてひび割れが発生する点とする。コンクリートの引張 り強度は $1.8 \sqrt{\sigma_{\mathrm{y}}}\left(\sigma_{\mathrm{y}}:\right.$ 圧縮強度 $\left.\left(\mathrm{kgf} / \mathrm{cm}^{2}\right)\right)$ とし、軸力 $\mathrm{N}$ が加 わる時にひび割れが発生する曲げモーメント $M_{C}(N)$ は (1) 式で与え る $^{9)}$ 。曲率 $\phi_{\mathrm{C}}(\mathrm{N})$ は (2) 式で求める。

$$
\begin{aligned}
M_{c}(N) & =1.8 \sqrt{\sigma_{y}} \cdot Z e+N \cdot D / 8 \\
\phi_{C}(N) & =M_{C}(N) /(E C \cdot I e)
\end{aligned}
$$

ここに、Ze：杭体の弾性時断面係数、D : 杭直径、

Ec·Ie : 杭体の弾性時曲け剛性

ii) 第 2 折れ点 $\left(\phi_{\mathrm{Y}}(\mathrm{N}) 、 M_{\mathrm{Y}}(\mathrm{N})\right)$

圧縮側あるいは引張り側の縁鉄筋が降伏する点とする。曲げモ一 メント $M_{Y}(\mathrm{~N})$ は、文献 9)の柱の短期許容応力度の算定と同様とする。 すなわち、軸力 N が加わる時の圧縮側あるいは引張り側の縁鉄筋が 降伏する (短期許容応力度に達する) モーメント $M_{\mathrm{Y}}(\mathrm{N})$ と中立軸位置 $\mathrm{x}_{\mathrm{y}}(\mathrm{N})$ を収束計算により求める。その際、歪み分布は平面保持を仮 定し、コンクリートの引張り強度は無視する。曲率 $\phi_{\mathrm{Y}}(\mathrm{N})$ は (3) 式 で求める101。

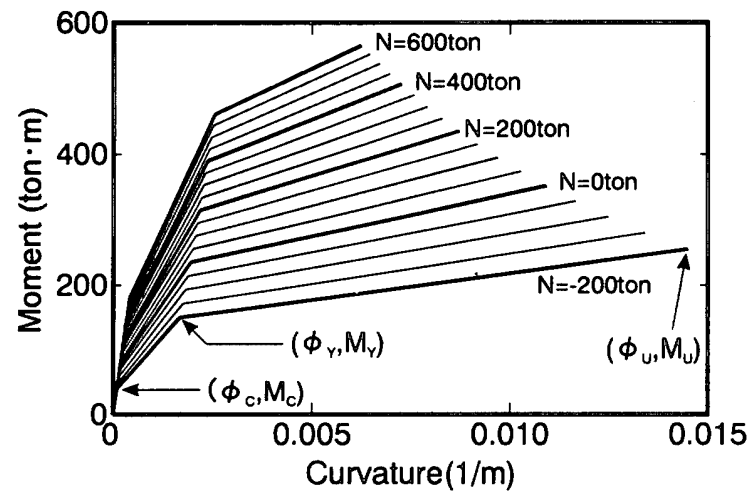

Fig.1 Skeleton curves dependent on axial force

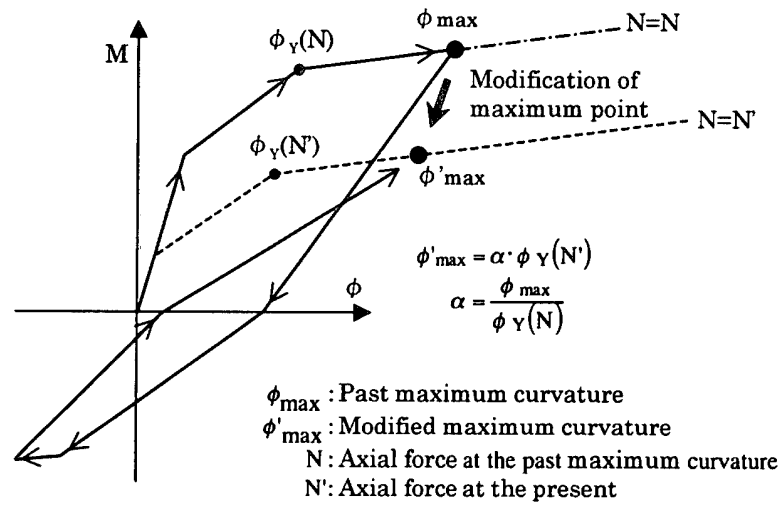

Fig.2 Hysterisis rule

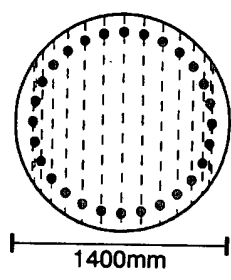

Fiber division

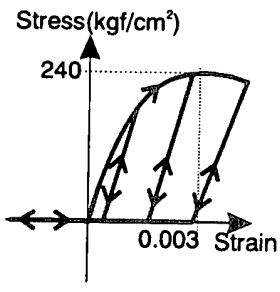

(a) Concrete

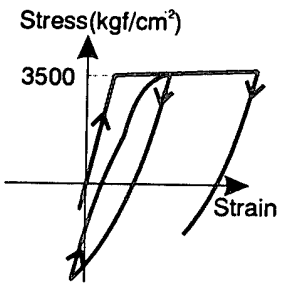

(b) Steel
Fig.3 Relationships between stress and strain
$\phi_{\mathrm{Y}}(\mathrm{N})=\varepsilon_{\mathrm{Y}} / \mathrm{x}_{\mathrm{Y}}(\mathrm{N})$

ここに、 $\varepsilon_{\mathrm{y}}$ : 鉄筋の降伏歪み、

$\mathrm{x}_{\mathrm{Y}}(\mathrm{N})$ : 杭断面における降伏鉄筋から中立軸までの距離

iii）終局点 $\left(\phi_{\mathrm{U}}(\mathrm{N}) 、 \mathrm{M}_{\mathrm{U}}(\mathrm{N})\right)$

圧縮側の縁コンクリートが圧壊する(限界圧縮歪み $0.3 \%$ に達する) 点とする。曲げモーメント $M_{v}(N)$ は、文献 11)の曲げ終局強度の算 定と同様とする。すなわち、圧縮縁コンクリートの歪みを限界圧縮 歪みとし、歪み分布に平面保持を仮定して応力分布を設定し、収束 計算により軸力 $N$ と曲げモーメント $\mathrm{M}_{\mathrm{V}}(\mathrm{N})$ の釣り合いが取れるよう に中立軸位置 $x_{v}(N)$ と $M_{v}(N)$ を求める。その際、コンクリートの引張 り強度は無視し、圧縮側のコンクリートは平均強度 $0.85 \cdot \sigma_{\mathrm{y}}$ のス トレス・ブロックを仮定する。鉄筋の応力ー歪み関係は完全弾塑性 とする。曲率 $\phi_{\mathrm{U}}(\mathrm{N})$ は (4) 式で求める10)。

$\phi_{\mathrm{U}}(\mathrm{N})=\varepsilon_{\mathrm{U}} / \mathrm{x}_{\mathrm{U}}(\mathrm{N})$

ここに、 $\varepsilon_{\mathrm{U}}$ : コンクリートの限界圧縮歪み $0.3 \%$ 、

$\mathrm{x}_{\mathrm{U}}(\mathrm{N})$ ：杭断面における圧縮側縁部から中立軸までの距離

Fig. 1 に、軸力を変化させて算定した場所打ちコンクリート杭の 骨格曲線を示す。軸力 N は、後出の地震応答解析結果を参考に構造 物の長期軸力 $200 \mathrm{t}$ on を規準に \pm 400 ton の変動を考え、 $N=-200$ 〜 600 t on まで変化させた。以下、圧縮は正、引張りは負の軸力とする。 杭体の強度は軸力の増加とともに上昇するが、第 2 折れ点から終局 点に至る変形量は減少し、杭体の変形性能が軸力に大きく依存する ことがわかる。

軸力変動を考慮した骨格曲線に対する履歴則は、Fig. 2 に示すよ うに設定した。すなわち、一定軸力下では従来の剛性劣化型の履歴 則 ${ }^{2}$ 2) とする。変動軸力下では、現時刻以前に経験した最大塑性率 を $\alpha\left(=\phi_{\max }(\mathrm{N}) / \phi_{Y}(\mathrm{~N})\right.$ ここに、 $\phi_{\mathrm{Y}}(\mathrm{N})$ : 第 2 折れ点の曲率、 $\phi_{\max }(\mathrm{N})$ : 最大曲率、 $\mathrm{N}$ : 最大曲率を示した時の軸力）とすると、現 時刻の軸力 N'において除荷状態から再び載荷状態に戻る際の骨格曲 線上の最大曲率は、 $\alpha$ を用いて修正した最大曲率 $\phi^{\prime}{ }_{\max }\left(\mathrm{N}^{\prime}\right) \quad(=\alpha$. $\left.\phi_{Y}\left(N^{\prime}\right)\right)$ とする。応答解析では、杭位置の違いにより時々刻々変化 する軸力に応じた非線形特性を用いて時刻歴解析を行う。

\section{2 ファイバーモデルとの比較}

上記の変動軸力を考慮した非線形特性モテルの有効性を確かめる ため、杭断面のファイバーモテル ${ }^{6)}$ による静的漸増解析結果と比較 する。ファイバーモデルの加力パターンは、一定軸力下の静的単調 加力と変動軸力下の繰り返し漸増加力の 2 種類を行う。ファイバー モテルに用いるコンクリートの応カー歪み関係は、引張り強度は無 視し、圧壊後の耐力低下を考慮した Fig. 3 (a)に示すモデル ${ }^{13}$ ) と した。鉄筋の応力ー歪み関係は、Fig. 3 (b)に示す 2 折れ線とした。

Fig. 4に、軸力 $\mathrm{N}$ をー200、0、200、600ton とした場合のファイ バーモテルと 3 折れ線モテルの骨格曲線を比較して示す。図中のフ アイパーモデルによる $M ー \phi$ 曲線上には、縁コンクリートのひび割 れが生じる点 $\left({ }_{\mathrm{F}} \mathrm{M}_{\mathrm{CC}}\right) 、$ 縁鉄筋の降伏する点 $\left({ }_{\mathrm{F}} \mathrm{M}_{\mathrm{YS}}\right)$ 、縁コンクリートが 圧壊する点 $\left(\mathrm{F}_{\mathrm{N}} \mathrm{M}_{\mathrm{vC}}\right)$ を示している。ファイバーモデと比較し、3 折 れ線モテルは低軸力下になるほど第 1 折れ点のモーメントが大きく なり、第 2 折れ点から圧壊点にかけてのモーメントを小さく評価す るが、杭体の変形性能を規定する第 2 折れ点と圧濖点はほほ一致し ている。

Fig. 5 (a)に、繰り返し加力によるファイバーモテルと 3 折れ線 
モデルの履歴曲線を比較して示す。モーメントの加力振幅は、Fig 5 (b)に示すように、第 1 サイクルで $M_{c}$ 、第 2 サイクルで $M_{\mathrm{y}}$ 、第 3 サイクルで $M_{\mathrm{v}}$ に至るものとした。その際：モーメントの増減ととも に軸力も増減させた。曲げモーメント $(M)$ と軸力 $(N)$ の比 $M / N$ は、圧 縮側で 1.6 (単位 : ton·m/m) とし、引張り側で 0.63 とした。この比
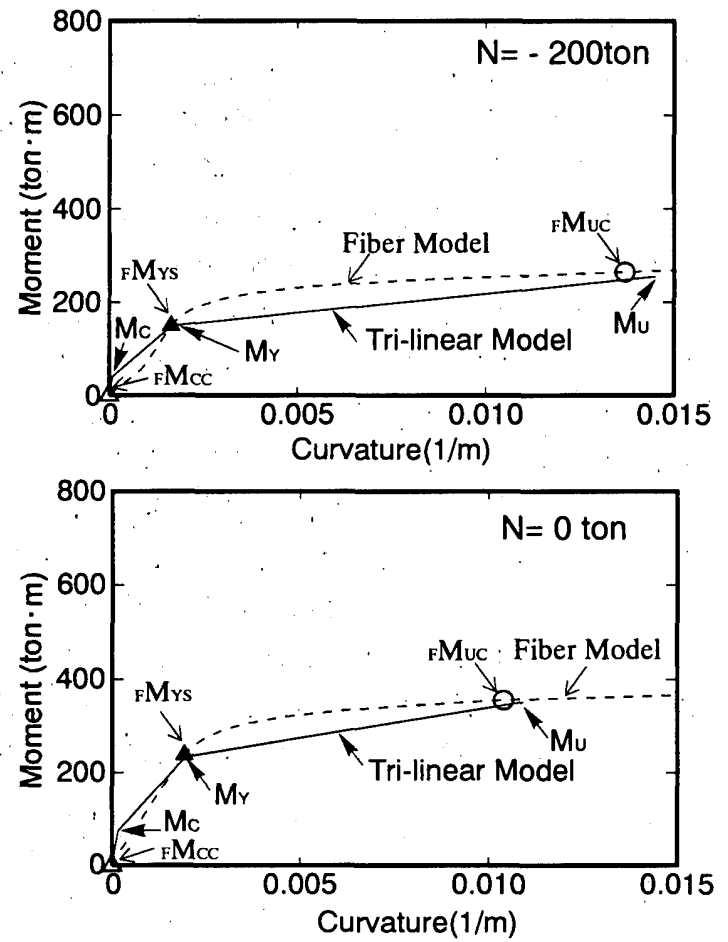

率は、後出する地震応答解析による杭頭部での応答結果をもとに設 定した。Fig. 5 (a)をみると、 3 折れ線モテルの非線形特性は曲率 の小さい領域で履歴ループはやや大きくなるが、第 2 折れ点から压 壊点に至る剛性、変形特性は良く対応しており、提案モテルの有効 性が確認できる。
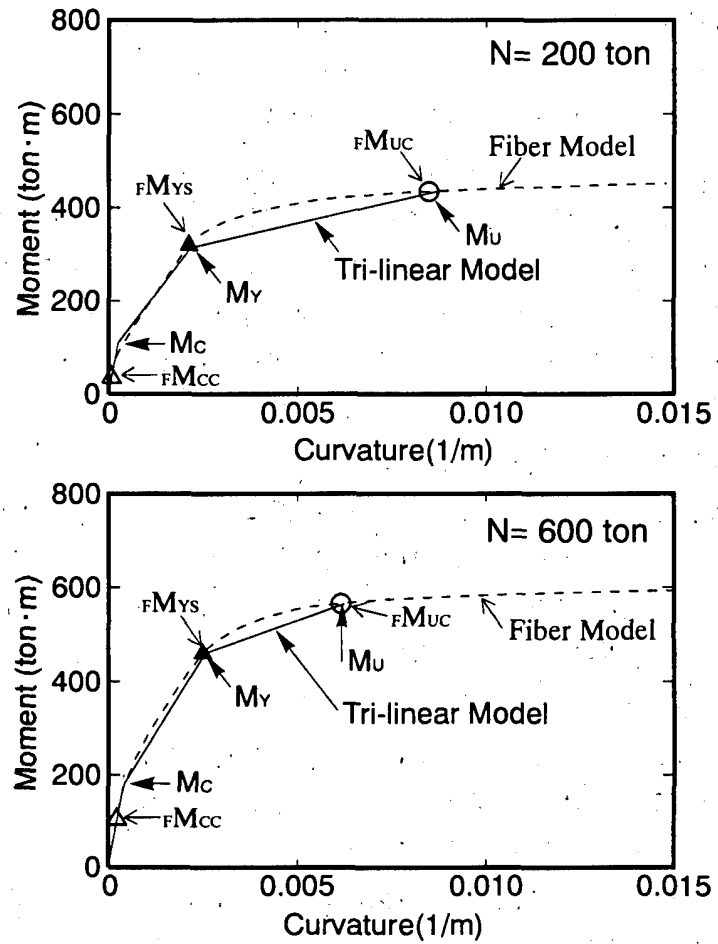

Fig.4 Comparisons of skelton curves between tri-linear model and fiber model
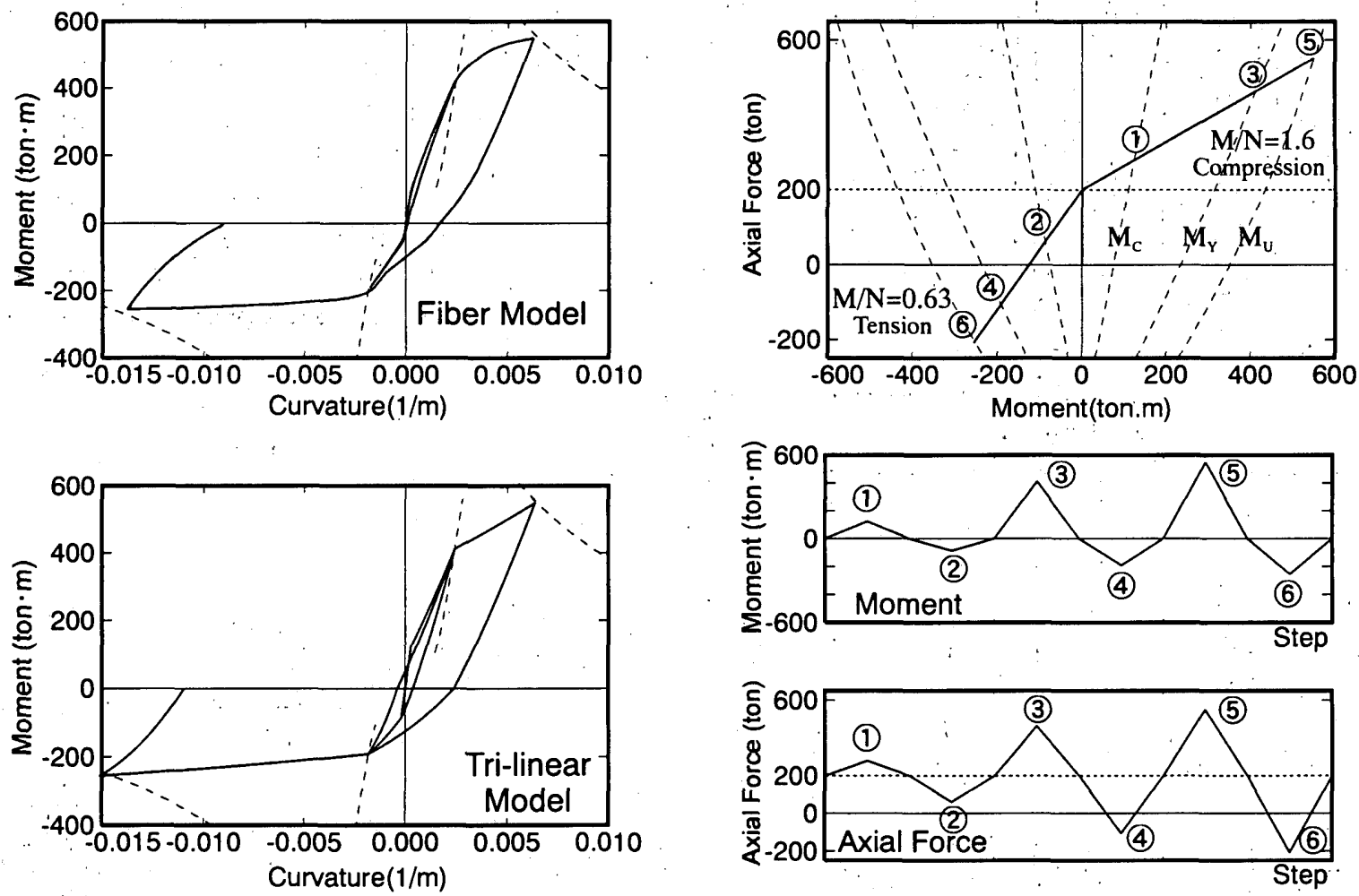

(a) Relationships between bending moment and curvature

(b) Loading conditions

Fig.5 Comparisons of hysteresis curves between tri-linear model and fiber model 
3. 杭支持構造物の地震応答解析

\section{1 入力地震波之地盤応答}

入力地震波は、兵庫県南部地震におけるポートアイランド GL-83m の水平 NS 方向観測波（最大加速度 679Gal）14）を用いた。なお、 観測波の方位補正はその影響が小さいとして行っていない。地盤は、 Fig. 6 に示すポートアイランド観測地点の地盤モデル ${ }^{14)}$ とした。 自由地盤の応答解析は、一次元有効応力解析法 (DESRA) ${ }^{15}$ ) を用い て行った。

Fig. 7 に自由地盤の応答結果として最大過剩間隙水圧、加速度、 杭の支持層(GL-38m)に対する相対変位分布を示す。なお、解析結果 と観測記録の比較は文献 3)において実施しており、解析は観測と 良い対応を示している。地盤応答は、GL-19m 以浅の埋立層で過剩間 隙水圧が上昇し、GL-12m 以浅では完全液状化となっている。最大加 速度は液状化した埋立層で低減するが、最大相対変位は大きく増幅 している。

\section{2 杭支持構造物の解析モデル}

上部構造物は、Fig. 8 に示す仮想の鉄筋コンクリート造 8 階建て （2×3 スパン、重量W: 2400 ton）の短辺方向（基礎固定時 1 次周期 $\mathrm{T}_{1}$ ： 0.5 秒)で、塔状比（建物高さ/幅)は 2.2 である。基礎の根入れは考 慮せず、各柱下を 1 本の場所打ちコンクリート杭(合計 12 本)で支 持した杭基礎とした。杭頭は基礎に剛接合とした。杭の諸元は TABLE 1 に示したように、直径は $1400 \mathrm{~mm}$ 、主鉄筋は SD345、鉄筋比は杭全 長について 1.2\%(28-D29) とした。長期軸力は 200 ton である。杭の 支持層は GL-38m の洪積砂砂層とした。

Fig. 9 に地震応答解析モデルを示す。上部構造物は 1 本の曲げせ ん断棒モデルとする。12 本の群杭は加振方向に 3 列 (1 列 4 本)の杭
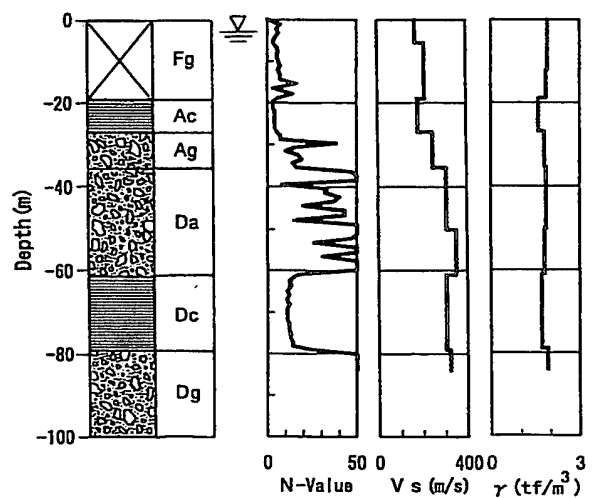

Fig.6 Soil profile

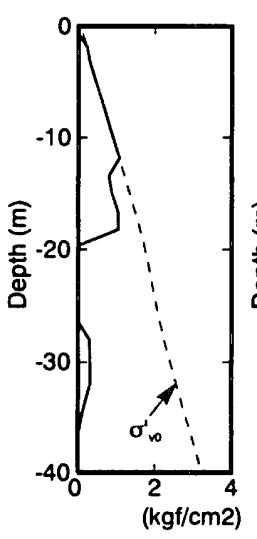

(P.W.P.)

Fig. 7 Maxim

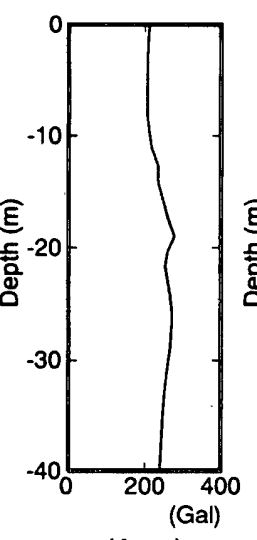

(Acc.)

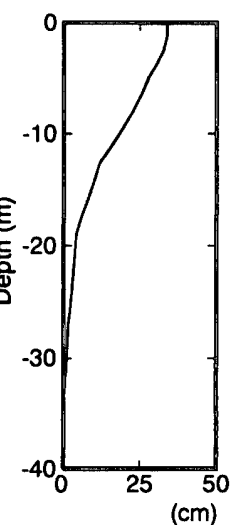

(Relative Disp.) tree ground
にまとめ、それぞれの杭列を 1 本の曲げせん断棒にモデル化する。 各杭には相互作用ばねを取り付け、このばねを介して自由地盤の応 答から得られた各深さの水平変位波形を入力して、上部構造物一杭 基礎一体モテルによる時刻歴応答解析を行う。减衰は内部粘性減衰 とし、構造物の一次固有周期に対して上部構造物は $3 \%$ 、杭は $1 \%$ とした。

相互作用ばねの初期定数は、自由地盤の全応力解析から得られた 等価地盤定数を用いて算定した。その算定は、三次元薄層要素法に よるリング加振解 $(\mathrm{f}=0.1 \mathrm{~Hz}$ の值)を用いて求めた群杭全体のフルマ トリックスの地盤ばねに対し、水平変形とせん断変形の 2 種類の変 位モードを与えることにより得られる各質点位置での地盤反力から、 水平地盤ばねとそれを結ぶせん断地盤ばねを評価した ${ }^{161}$ ，17)。 また非線形地盤では地盤剛性が小さくなり、杭位置による地盤ばね

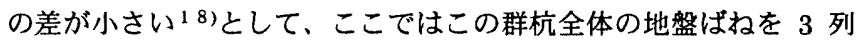
の杭に均等に配分することにより、各杭列のばねを評価した。この 相互作用ばねに、杭と地盤との相対変位により生じる非線形性を考 慮し、さらに自由地盤の過剩間隙水圧の上昇、消散にともなう有効 応力の変動による拘束圧依存性の非線形性を取り入れる。基礎底面 の回転ばねは、水平ばねと同様に三次元薄層要素法を用いて基礎底 面中心位置における群杭の回転ばねを求めた。相互作用ばねの評価 法と非線形特性の詳細については、文献 16)，17）を参照されたい。 また、本解析モデは、飽和地盤における杭基礎の遠心模型実験結

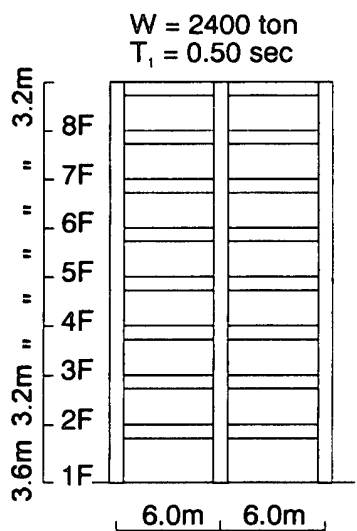

(a) Elevation $n=4 \times 3$ $\mathrm{s} / \mathrm{d}=4.3$

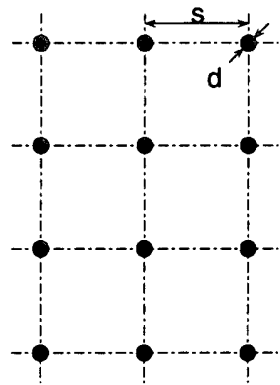

(b) Pile arrangement
Fig.8 Superstructure-pile foundation model

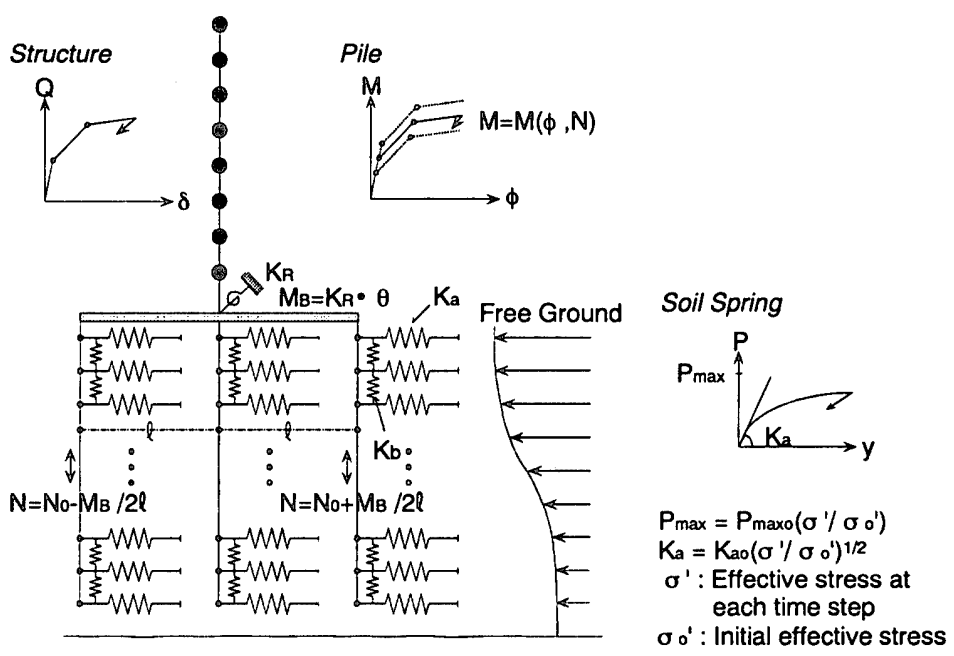

Fig.9 Numerical model for superstructure-pile foundation system 
果との比較により有効性を確認している ${ }^{17) 。 ~}$

杭体の曲げモーメント Mー曲率 $\phi$ の関倸は、先に示した軸力依存 を考慮した非線形特性とする。なお、解析では緣コンクリートが圧 壊する終局点以降については第 3 剛性を維持するものとし、せん断 剛性は線形とした。杭体の変動軸力は、時々々刻々得られる上部構造 物からの転倒モーメント(基礎底面の回転ばねの反力)を三角形分布 と仮定し杭位置により配分し、杭頭から杭先端まで同じとした。す なわち、杭の軸㓮性は線形として扱い、杭周面の摩擦ばねは小さい と仮定している。

上部構造物の復元力特性は、柱梁部材に非線形特性を与えたフレ 一ムモテルの静的漸増解析により層せん断力 Q-層間変形 $\delta$ の関係 を求め、層毎に 3 折れ線モデルに近似した。履歴則は杭体の曲げ非 線形特性と同じ剛性劣化型モデル ${ }^{12)}$ とした。

\section{4. 杭基礎の地震応答}

Fig. 10 に各杭の応答最大曲げモーメント、せん断 力分布を示す。外側杭である Pile-1、Pile-3 には変 動軸力が加わっているが、中央杭である Pile-2 には 変動軸力が発生していない。各杭の応力は杭頭および 液状化層と非液状化層の境界である GL-19m 位置で大 きな值となり、変動軸力の違いにより Pile-3 が杭全 長にわたり大きな応答を示している。杭頭でのせん断 力の違いは、変動軸力により杭体の曲け剛性と耐力に 差が生じ、上部構造物からのせん断力の配分が杭位置 により異なるためである。また、杭頭の曲げモーメン トには、上部構造物のせん断力により生じた応力に比 べ液状化地盤の地盤震動により生じた応力の寄与が大 きくなっている3),4)。

Fig.11 に各杭頭における曲げモーメント、せん断 力、軸力の時刻歴波形を示す。各波形とも衝撃型の波 であったポートアイランド波の入力によって、入力動 の初期の段階に振幅の大きい波が数波続いている。周 期成分は約 1 2 秒の波が卓越し、同（逆）位相に近い 波形となっている。1〜2秒の周期成分は、この周期 帯でパワーをもつ入力地震動により液状化地盤の応答 が卓越した周期帯域であり、それの入力により上部構 造物が非線形化し長周期化したものである ${ }^{3)}$,4)。Pile-3 の曲げモ 一メント、せん断力波形は 6.5 秒付近において最大值を示し、軸力 は最大圧縮力が加わっている。同時刻に Pile-1 は最大引張り軸力 となり、Pile-3 や変動軸力のない Pile-2 に比べ小さい杭応力とな る。次に 7.4 秒付近では、Pile-1 と Pile-3 に生じる軸力の正負が 入れ替わり、圧縮軸力となる Pile-1 の杭応力が最大值となる。

Fig. 12 に、6.5 秒における各杭の曲げモーメント、せん断力分布 を示す。最大圧縮軸力が加わっている Pile-3 は杭全長にわたり大 きな応力を示し、杭頭と GL-19m 位置では変動軸力のない Pile-2 に 比較して約 1.4 倍となる。一方、最大引張り軸力となる Pile-1 で は約 0.5 倍と小さい応力となっている。この応力の差は、杭位置に より変動軸力が異なることにより杭体の曲け剛性と耐力に差が生じ ているためである。

Fig. 13 に、各杭の杭頭と.GL-19m 位置における M-N 曲線を示す。

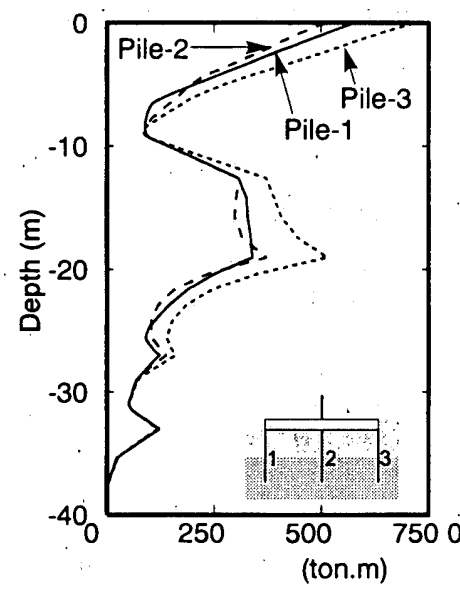

(Bending Moment)

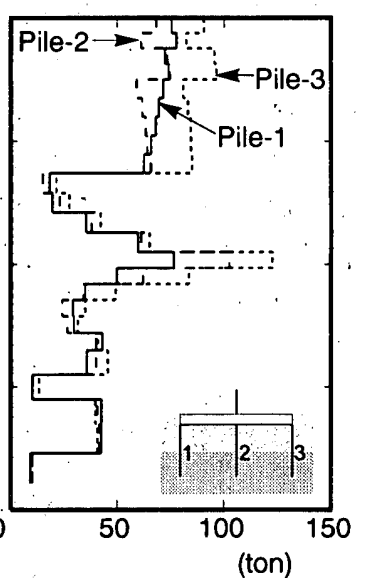

(Shear Force)
Fig.10 Distributions of maximum responses of piles

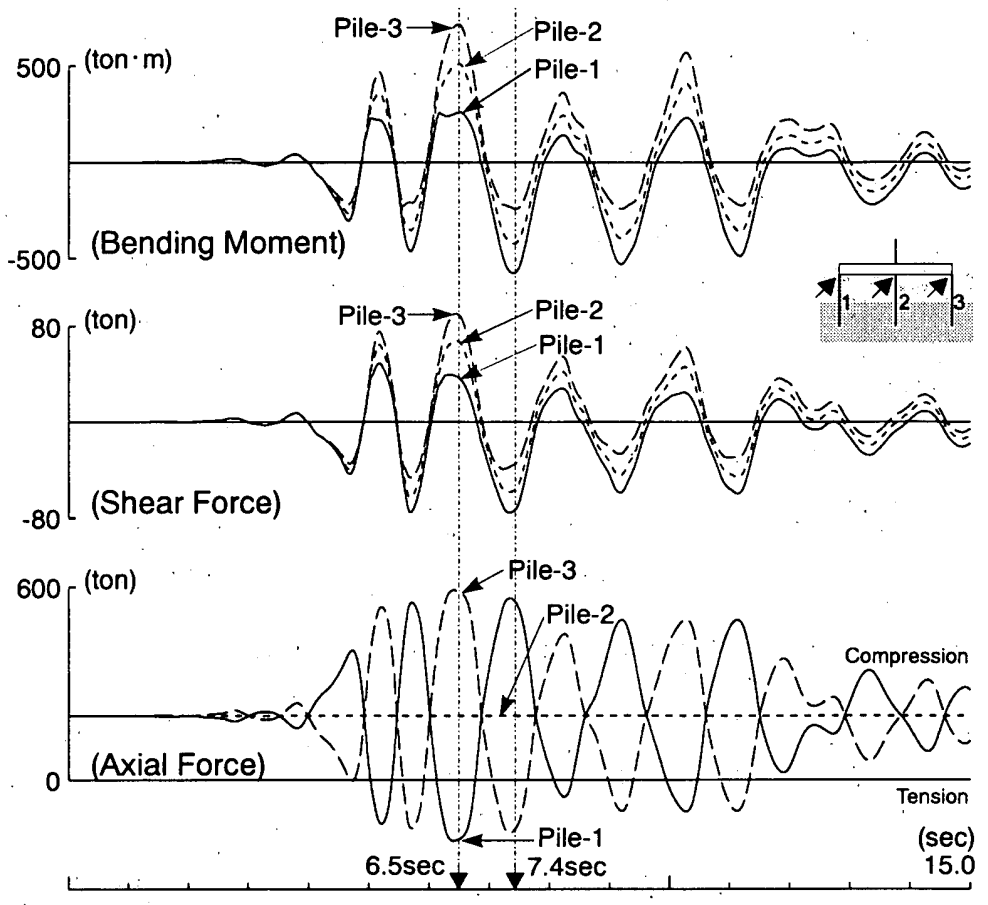

Fig.11 Time histories of pile responses at the pile head

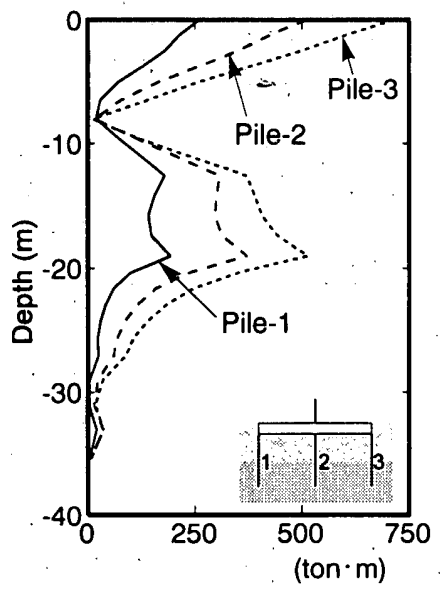

(Bending Moment)

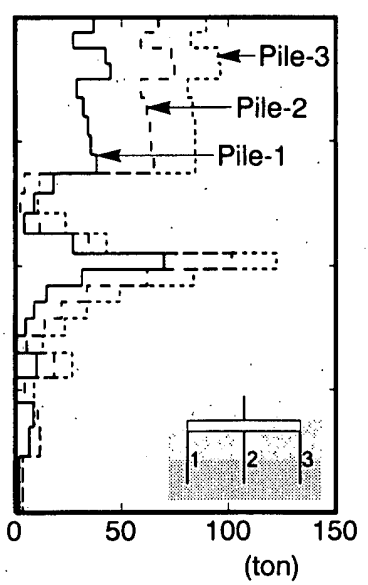

(Shear Force)

Fig.12 Distributions of pile responses at $6.5 \mathrm{sec}$ 
図中には、縁コンクリートのひび割れモーメント M、縁鉄筋の降伏

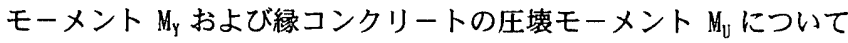
の M-N 関係も示している。Pile-1 と Pile-3 の曲げモーメントと軸 力の関係は、Fig. 11 に示したように両波形はほぼ同(逆)位相となる ため、履歴面積の小さい形状となる。杭頭での塑性化状況は各杭と も $M_{\mathrm{Y}}$ を越え、Pile-3 は最大圧縮軸力となる 6.5 秒で $M_{\mathrm{U}}$ を大きく越 えている。軸力変動のないPile-2 も同時刻でM $M_{U}$ に達している。Pile-1
は引張り軸力となりモーメントは增大しているが、 $M_{U}$ を越えていな い。しかし、次に最大圧縮軸力となる 7.4 秒で $\mathrm{M}_{\mathrm{U}}$ に達している。一 方、液状化層の下端部に相当する GL-19m 位置では杭頭とは逆位相

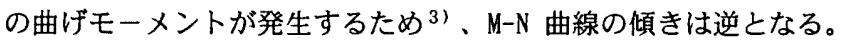
6.5 秒では全ての杭が $M_{\mathrm{Y}}$ を越えているが、M $M_{\mathrm{U}}$ には達していない。

Fig. 14 に、各杭の杭頭と GL-19m 位置における M示す。図中には、軸力を変化させた時の降伏点 $M_{Y}\left(\phi_{Y}\right)$ と圧壊点
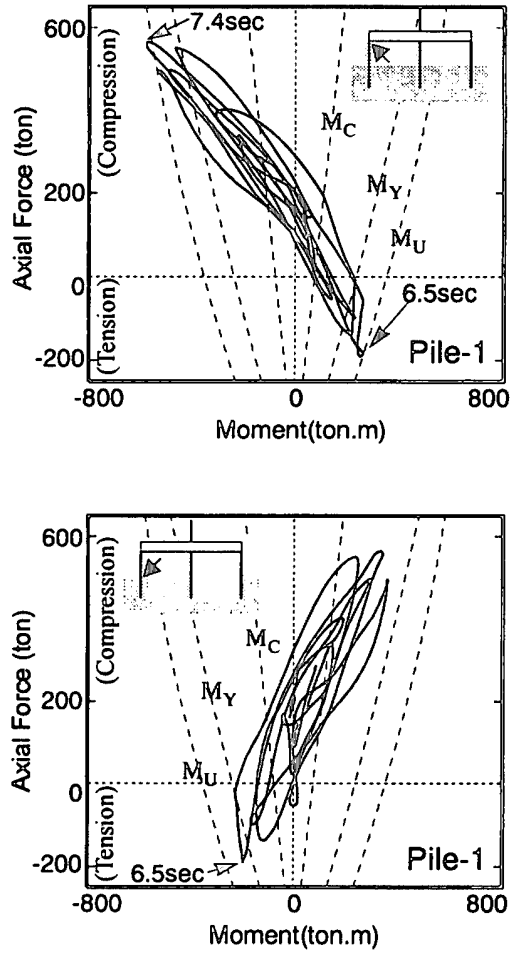

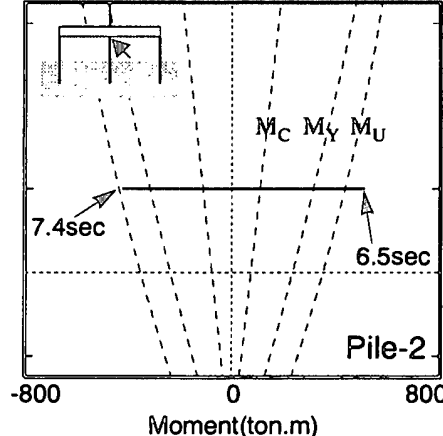

(Pile Head)

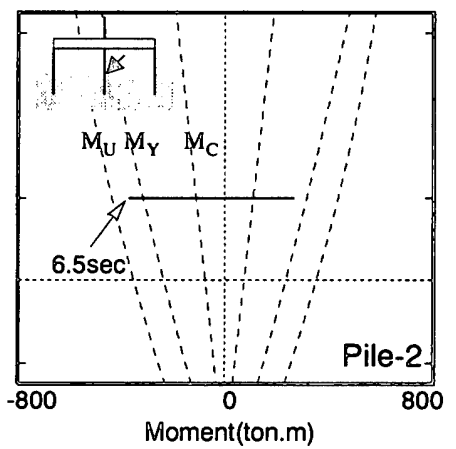

(G.L.-19.0m)
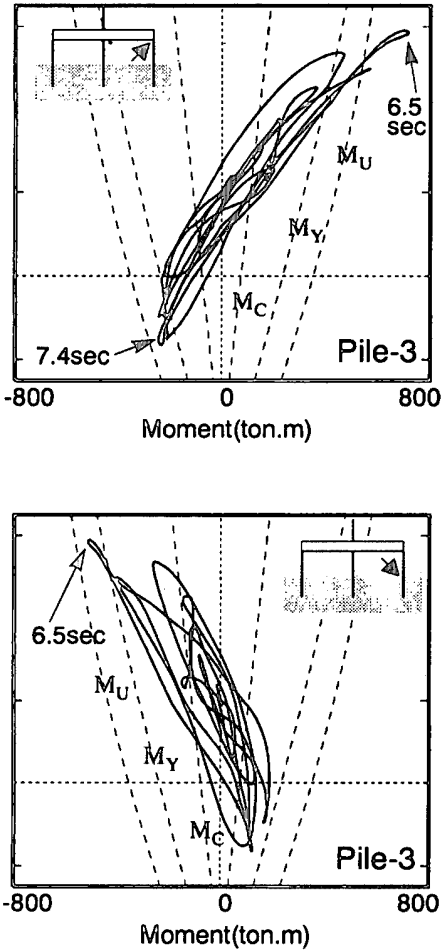

Fig.13 Relationships between bending moment and axial force at the pile head and G.L.- $19 \mathrm{~m}$ of Pile-1,2 and 3
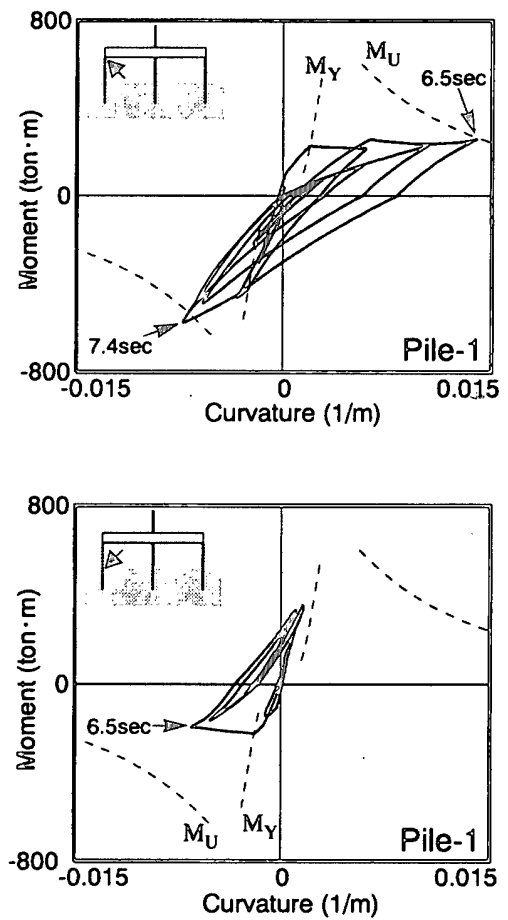

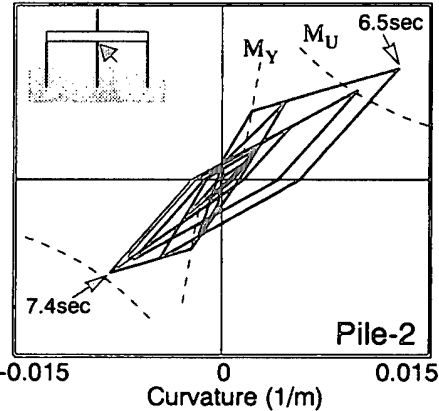

(Pile Head)

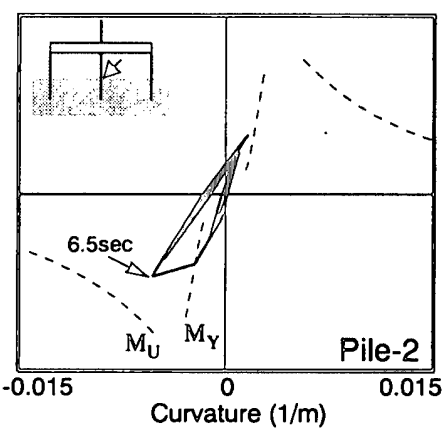

(G.L.-19.0m)
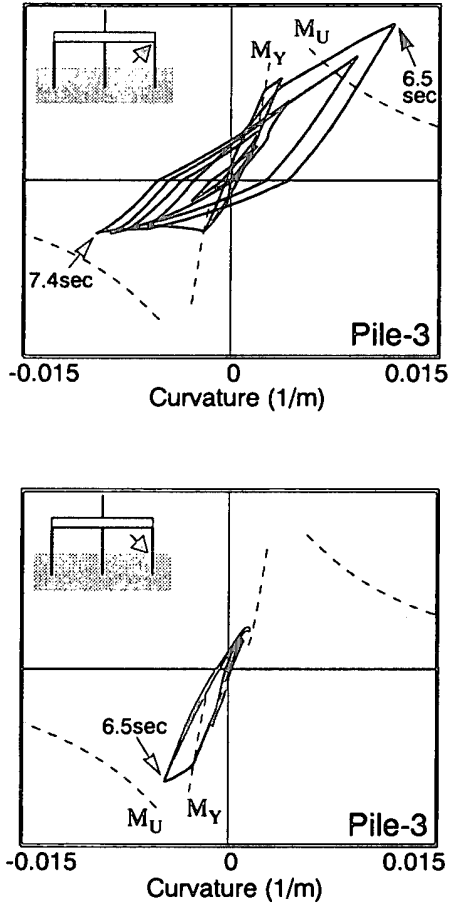

Curvature $(1 / \mathrm{m})$

Fig.14 Relationships between bending moment and curvature at the pile head and G.L.-19m of Pile-1,2 and 3 
$M_{\mathrm{u}}\left(\phi_{\mathrm{U}}\right)$ の軌跡を示している。変動軸力がない Pile-2 は、通常の剛 性劣化型の 3 折れ線の履歴曲線となる。Pile-1 の杭頭では、第 1 象 限の引張り軸力下では曲け剛性、耐力は低下し、逆に第 3 象限では 圧縮軸力により上昇している。引張り軸力下で応答最大曲率となる 6.5 秒付近では、曲げモーメントは頭打ちとなり塑性化が大きく進 展しているが、M $M_{U} に は$ 達していない。GL-19m 位置では、杭頭と曲げ モーメントが逆位相となるため、第 3 象限において引張り軸力によ り曲け剛性、耐力が低下している。一方、Pile-3 の杭頭では、Pile-1 と逆位相の軸力となり 180 度回転した履歴曲線となる。第 1 象限で は、压縮軸力下となるため $M_{Y}$ から $M_{U}$ までの変形性能は小さくなり、 6.5 秒では曲率の增大とともに大きく $M_{10}$ を越える結果となる。

Table 2 に杭頭と GL-19m 位置の最大塑性率を示す。最 大塑性率は、6.5 秒における各杭の最大曲率 $\phi_{\max }$ を、そ れぞれの軸力における縁鉄筋の降伏点 $\phi_{\mathrm{Y}}$ で除すことによ り求めている。また、その軸力における縁コシクリートの 圧壊点 $\phi_{\mathrm{U}}$ の $\phi_{\mathrm{Y}}$ に対する比（以下、終局塑性率という。）も 併せて示す。最大塑性率がこの終局塑性率以下であれば圧 壊点に達していないことを示している。杭頭での最大塑性 率をみると、最大圧縮軸力となる Pile-3 の塑性率は 4.6 とあまり進んでいないが、終局塑性率 2.5 を大きく越えて いる。一方、最大引張り軸力となる Pile-1では、塑性率 は 8.2 と大きく進展しているが、変形性能も增大するため 終局塑性率 8.3 には達していない。このように、杭基礎の

Table 2 Ductility of pile responses

\begin{tabular}{|c|c|c|c|c|}
\hline \multicolumn{2}{|c|}{} & Pile-1 & Pile-2 & Pile-3 \\
\hline \multirow{2}{*}{$\begin{array}{c}\phi_{\max } / \\
\phi_{Y}\end{array}$} & Pile Head & 8.2 & 5.9 & 4.6 \\
\cline { 2 - 5 } & G.L.-19m & 3.9 & 2.4 & 1.8 \\
\hline \multicolumn{2}{|c|}{$\phi_{U} / \phi_{Y}$} & 8.3 & 4.0 & 2.5 \\
\hline
\end{tabular}

変形 (被害) 状況を評価する工学量として最大塑性率を用いる場合、 軸力変動により杭位置によって異なる杭体の変形性能を考虑して性 能評価をする必要がある。

\section{5. 上下動入力の影響}

地震時に杭に生じる軸力は、“先で検討した水平動入力による構造 物の転倒モーメントにより発生する軸力の他に、上下動入力による 構造物の上下応答にともない発生する軸力がある。ポートアイラン ド地点の鉛直アレー観測では、埋立層の液状化層では水平動の最大 加速度值は低減したが、上下動は増幅する記録が得られておりり ${ }^{14) 、}$

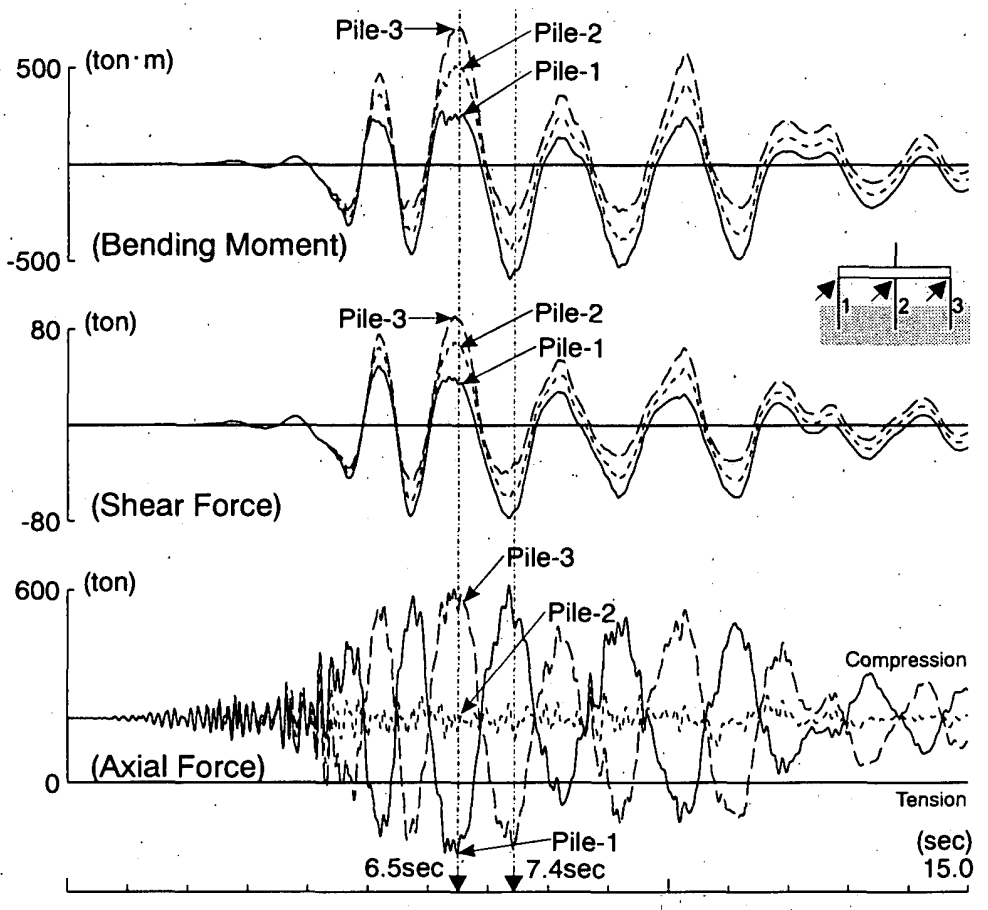

Fig.15 Time histories of pile responses at the pile head
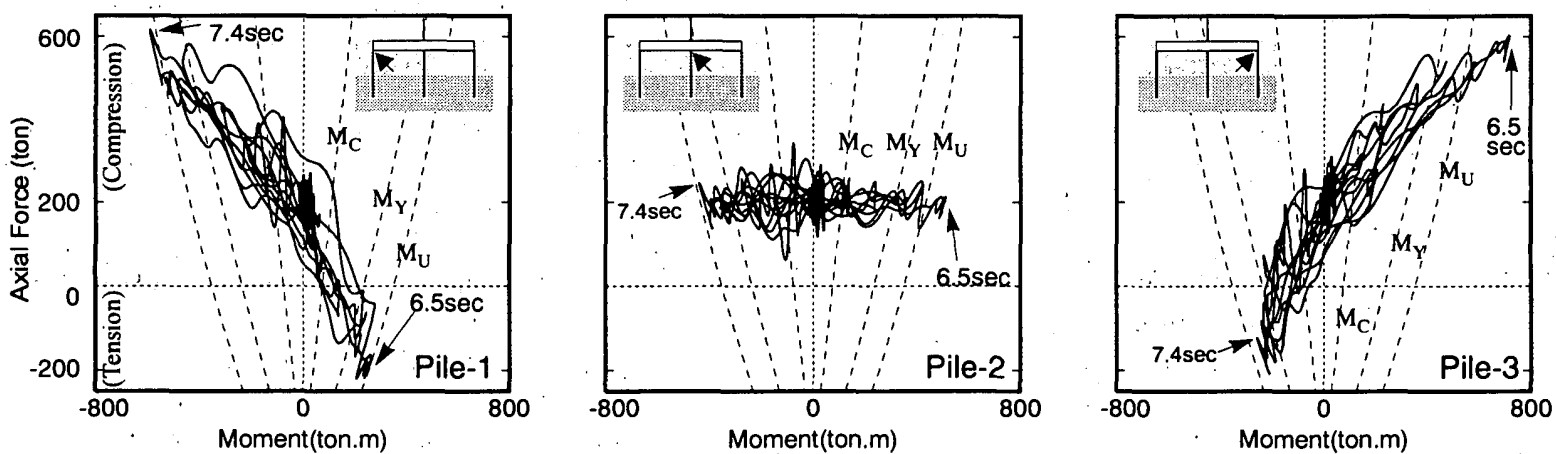

Fig.16 Relationships between bending moment and axial force at the pile head of Pile-1,2 and 3
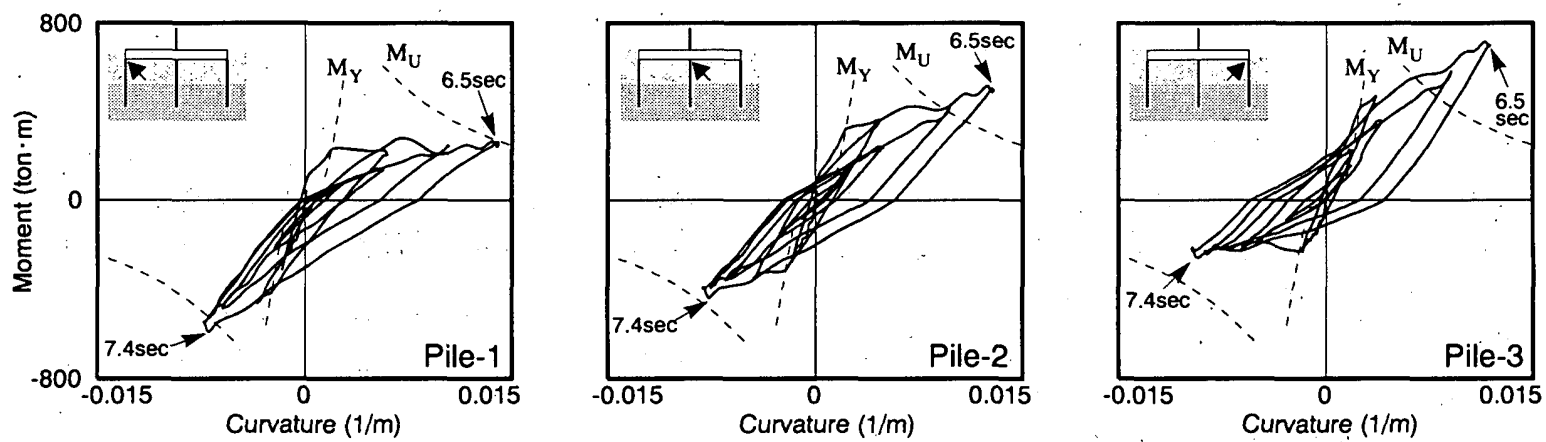

Fig.17 Relationships between bending moment and curvature at the pile head of Pile-1,2 and 3 
構造物の上下応答も大きかったことが考えられる。ここでは、構造 物の上下応答による軸力変動が杭基礎の応答に与える影響を検討す る。

解析は、まず上部構造物の上下動地震応答解析を別途簡易モテル で行い、上下応答による各杭の軸力を一様分布として算定する。次 に、先に示した水平動入力時の地震応答解析において、上下動入力 時の軸力変動を同時に考慮しながら応答解析を行った。上部構造物 は柱断面の軸剛性から算定した一本棒の軸ばねモテルとし、線形と した。基礶底面には群杭の上下方向の相互作用ばねを取り付けた。 上下方向の相互作用ばねは、回転ばねと同様に等価地盤定数を用い て三次元薄層要素法による成層地盤内のリング加振解により評価し た。入力地霞動には、ポートアイランド GL0m で観測された上下動 成分 $(555.9 \mathrm{Gal})$ を用いた。なお、上下方向の構造物一群杭一地盤連成

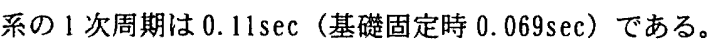

解析結果として、Fig. 15 に各杭頭における曲げモーメント、せん 断力、軸力の時刻歷波形を示す。Fig. 16 に各杭の杭頭における M-N 関俰を、Fig.17 にM- $\phi$ 履歴曲線を示す。上下動入力における軸力 変動はPile-2 の軸力波形にみることができる。その振動数成分は、 水平動入力時の転倒モーメントによる軸力波形に比べ高振動数成分 は卓越するが、最大値は約 $1 / 3$ 程度であり、両者の最大値生起時 刻に差がある。M-N 関係は、Fig. 13 に示した水平動入力時のみに比 べ変動は大きくなり複雑なものとなるが、杭体の最大応力と塑性率 はほほ同程度であり、上下動入力の与える影響は小さいことがわか る。

\section{6. まとめ}

兵庫県南部地震時のポートアイランド波を入力動として、場所打 ちコンクリート杭の $\mathrm{M}$ - $\phi$ 関係に軸力依存性を考虑した地震応答解 析を実施し、軸力変動が杭応答に及ぼす影響について検討した。本 研究で得られた成果を、以下にまとめて示す。

（1）杭体の $M-\phi$ 関係に軸力変動を考慮した非線形特性モデルを示 し、ファイバーモデルによる結果と比較した。提案モデルは、曲 率の小さい領域で履歴ループはやや大きくなるが、縁鉄筋の降伏 から縁コンクリートが圧壊に至る剛性、変形特性は良く対応し、 提案モテルの有効性を確認した。

（2）変動軸力による杭体の $M-\phi$ 関係の違いにより、杭体に発生す る応力は杭位置により異なる。本解析では、最大曲げモーメント が発生した 6.5 秒において、軸力変動がない中央の杭に対して、 圧縮側の杭では最大曲げモーメントは 1.4 倍、引張り側の杭では 0.5 倍となる。また、杭位置の変動軸力の違いにより杭体の曲げ 魝性と耐力が異なるため、杭頭部では塑性化状況に大きな差が生 じ、上部構造物からのせん断力の配分が異なる。

（3）杭基礎の時系列での応答は、6.5 秒において各杭の杭頭部で $M_{Y}$ を越え、最大圧縮軸力となる杭と中立軸の杭で $M_{u}$ に達する。一方、 引張り側の杭では $M_{U}$ を越えないが、次に最大圧縮軸力となる 7.4 秒で $M_{U}$ に達する。液状化層の下端部にあたる GL-19m 位置では、6.5 秒において圧縮側と引張り側の杭とも $M_{\mathrm{Y}}$ を越えている。

（4）杭体の応答は、圧縮側と引張り側で終局点に至る変形量が異な るため、圧縮側の杭では塑性率はあまり大きくならないが終局点 に達する。一方、引張り側の杭では塑性率は大きなものとなるが
終局点に達しない。このことから杭基礎の耐霞性能を応答最大塑 性率で評価する場合、圧縮側と引張り側それぞれの軸力下での変 形性能を考慮して行う必要がある。

（5）構造物の上下応答による軸力は、構造物の転倒モーメントによ り発生する軸力に比べ高振動数成分は卓越するがその值は小さく、 上下応答が杭の最大応力と変形性能に与える影響は小さい。

なお、軸力変動の影響は、上部構造物の振動特性や入力地霞動の 特性により大きく変化することが考えられる。また、水平 2 方向入 力時に隅杭に発生する変動軸力は、水平 1 方向入力時に比べさらに 大きくなる場合があることが予想され、このような条件下での杭基 礎の応答については今後の課題としたい。

参考文献

1）日本建築学会近畿支部基礎構造部会、兵庫県南部地震建築基碳被害 調查委員会 : 兵庫県南部地震による建築基䃈の被害調査事例報告書、 1996. 7

2）阪神・淡路大震災調查報告編集委員会: 阪神・淡路大震災調查報告 建 築編-4、木造建築物・建築基䃈構造、日本建策学会、1998.3

3）宮本裕司、酒向裕司、古山田耕司、三浦賢治：1995 年兵庫県南部地震 の観測記録を用いた液状化地盤における杭基礎構造物の応答に関する 解析的㭘討、日本建築学会榑造系論文集、No.493、pp. 23-30、1997.3

4）宮本裕司：兵庫県南部地震における杭基礎の被害、第 5 回構造物と地 盤の動的相互作用シンポジウム、日本建築学会 基礎構造系振動小委員 会、pp. 33-44、1998.5

5）日本建築学会構造委員会 基礎構造運営委員会 : 建築基礎の設計施工に 関する研究資料 4、液状化地盤における基礎設計の考え方、1998.9

6）日本建築学会：建築耐震設計における保有耐力と変形性能 (1990)

7）茶谷文雄、秋野矩之、野村敦子他：兵庫県南部地震で被災した RC 杭 の被害分析、第 5 回構造物と地盤の動的相互作用シンポジウム、日本 建築学会 基礎構造系振動小委員会、pp. 193-198、1998.5

8）酒向裕司、宮本裕司、池田 孝: 杭の軸力変動が杭基礎の地震応答に 及ぼす影響、第 10 回日本地震工学シンポジウム、1998.11

9）日本建築学会 : 鉄筋コンクリート構造計算規準・同解祱、1991

10) 日本建築学会 : 鉄筋コンクリート煙突の侢造設計指針、1976

11)American Concrete Institute : Building Code Requirements for Reinforced Concrete (ACI-318-89) and Commentary

12)T. Takeda, M. A. Sozen, N. N. Nielsen:Re inforced Concrete Response to Simulated Earthquakes, Journal of the Structure Division, ASCE, ST12, pp. 2557-2573, 1970

13)鈴木紀雄、井上範夫、森川博司 : ファイバーモテルによる RC 短柱と 十字型部分骨組みの解析、コンクリート工学年次論文報告集、V01.15, No. 2, pp. $577-582,1993$

14) 神戸市開発局 : 兵庫県南部地震による埋立地地盤変形調査 (ポートア イランド、六甲アイランド) 報告書、平成 7 年 8 月

15)Finn H.D. L., K. T. Lee, G. R. Mart in : An Effective Stress Model for Liquefaction, Journal of the Geotechnical Eng. Division, ASCE, Vol.103, pp. 517-533, 1977

16）宮本裕司、酒向裕司、喜多村英司、三浦賢治：非線形、液状化地盤に おける杭基礎の地震応答性状に関する研究、日本建築学会構造系論文 報告集、第 471 号、pp. $41-50 、 1995.5$

17)宮本裕司、福岡篤信、安達直人、古山田耕司 : 液状化地盤における杭 基礎の地震時杭応力に関する研究（飽和二層地盤に建つ杭基礎の遠心模 型実験之解析的検討)、日本建築学会構造系論文集、N0.494、pp. 51-58、 1997.4

18）前田達哉、喜多村英司、岩本賢治、增田潔、三浦賢治：群杭基䃈の非 線形動的インピーダンス、第 9 回日本地震工学シンポジウム、 pp. 1213-1218、1994.12 